\title{
The occurrence of Hymenopenaeus debilis (Decapoda: Aristeidae: Solenocerinae) in Mediterranean waters: a case of pseudopopulations of Atlantic origin?
}

\author{
Joan E. Cartes $*$, Pere Abelló ${ }^{\dagger}$ and Pedro Torres ${ }^{\ddagger}$ \\ *Institut Mediterrani d'Estudis Avançats (IMEDEA-CSIC), Grta. Valldemossa, K. 7,5 07071 Illes Balears, Spain. \\ ${ }^{\dagger}$ Institut de Ciències del Mar (CSIC), Passeig Joan de Borbó s/n, 08039 Barcelona, Spain. ${ }^{\ddagger}$ Centro Oceanográfico de Málaga (IEO), \\ Puerto Pesquero s/n, 29640 Fuengirola (Málaga), Spain. ${ }^{\int}$ Corresponding author: e-mail: jcartes@icm.csic.es
}

\begin{abstract}
The occurrence of the aristeid shrimp Hymenopenaeus debilis in the Mediterranean Sea is reported from two individuals collected in the Alborán Sea and off Eivissa (western Mediterranean) from depths of 668-679 and 1109-1140 m, respectively. Comments on the origin of the populations and biogeography of the species are related to the Mediterranean pseudopopulations hypothesis.
\end{abstract}

The present paper reports the occurrence of Hymenopenaeus debilis S.I. Smith, 1882 in the Mediterranean Sea, based on the capture of two specimens, one in Alborán Sea (the westernmost part of the Mediterranean Sea) and another off Eivissa (Balearic Islands). The occurrence of this species of Atlantic origin in Mediterranean waters is discussed bearing in mind possible mechanisms of colonization and the hypothesis of Mediterranean pseudopopulations of Atlantic origin (Bouchet \& Taviani, 1992)

Two specimens were captured, an immature female (specimen 1:8.6 mm carapace length; $35 \mathrm{~mm}$ total length) captured in the Alborán Sea on the 12 May 1997 from a depth of 668-679 m off Málaga (M97-L12 sample; 36²1.06N $04^{\circ} 33.02 \mathrm{~W}$ ) (Figure 1), and a female (specimen 2:13.0 mm carapace length; $47 \mathrm{~mm}$ total length) captured in the south-west of the Balearic Islands off Eivissa from a depth of 1109-1140 m (Q2-10 sample: $38^{\circ} 26.36 \mathrm{~N} 01^{\circ} 47.39 \mathrm{E}$ ) on the 10 May 1998 (Figure 1). Both specimens were captured by bottom trawling, specimen 1 during a MEDITS-ES97 cruise performed on-board RV 'Cornide de Saavedra' (codend mesh size: $10 \mathrm{~mm}$ ), and specimen 2 during the QUIMERA-2 cruise performed onboard RV 'García del Cid' (codend mesh size: $6 \mathrm{~mm}$ ). Both specimens were deposited in the Biological Collections of the Instituto de Ciencias del Mar (CSIC) in Barcelona (code numbers ICMD-25/1999 and ICMD-26/1999).

The two specimens belong to the Hymenopenaeus group IV (Burkenroad, 1936), bearing both a branchiostegal spine (lacking pterygostomian spines) and two postrostral teeth separated from the rostral series. Both specimens bear six conicalshaped photophores arranged as in the descriptions provided by Burkenroad (1936) and Crosnier \& Forest (1973) for H. debilis. Coloration of both specimens immediately after capture was an almost uniform reddish-orange according to Bouvier (1908). The morphological characteristics of the examined specimens allowed their identification as belonging to the species Hymenopenaeus debilis. In the juvenile female, the ventral margin of rostrum (broken in specimen 2) was unarmed, bearing seven teeth on its dorsal margin. This lack of ventral spines on the rostrum may be a feature of juvenile individuals since Burkenroad (1936) states that 'in $H$. debilis the rostral armature is variable' and that 'up to three teeth may be present'. The size of our juvenile specimen 1 is much smaller than sizes reported by Crosnier \& Forest (1973).

Hymenopenaeus is a diversified genus of Penaeidea shrimps in Atlantic and Indo-Pacific waters. It is represented by five species in the eastern Atlantic Ocean (H. laevis, H. affinis, H. chacei, H. aphoticus, and H. debilis), all from tropical and subtropical waters. H. laevis and H. affinis are found south of latitude $20^{\circ} \mathrm{N}$ (Crosnier \& Forest, 1973). The northern limit for H. chacei seems to be the Canary Islands (González-Pérez, 1995), but it is also mainly distributed south of latitude $20^{\circ} \mathrm{N}$ (Crosnier \& Forest, 1973). The distribution of $H$. aphoticus in the eastern Atlantic is largely unknown and records have been reported south of the Açores and off Morocco (Crosnier \& Forest, 1973; Noël, 1992). H. debilis is the species that reaches farthest north in the eastern Atlantic, with records being found south of latitude $40^{\circ} \mathrm{N}$ (Maurin, 1962; Zariquiey-Álvarez, 1968; Crosnier \& Forest, 1973; González-Pérez, 1995; García-Raso, 1996). This species has been reported in the Bay of Cádiz, only on the Atlantic part of the Strait of Gibraltar (Zariquiey, 1968; García-Raso, 1996).

The westernmost area of the Mediterranean Sea, including the Alborán Sea and the south of the Balearic Islands, has a strong Atlantic hydrographical influence that could explain the capture of $H$. debilis in this area in the framework of the pseudopopulation hypothesis by Bouchet \& Taviani (1992), as an example of an Atlantic origin species.

Hymenopenaeus debilis is a deep sea species, Zariquiey-Álvarez (1968) report its overall occurrence between 100 and $2163 \mathrm{~m}$ which includes the depth interval of the present specimens reported in the Mediterranean. West of the Straits of Gibraltar, the species appears to be common in deep waters, since it appeared in $25 \%$ of the beam-trawl samples (9/36) taken between 180 and $2110 \mathrm{~m}$ in the Gulf of Cádiz by the Balgim expedition at depths of between 890 and $1527 \mathrm{~m}$ (García-Raso, 1996). By contrast, east of the Straits of Gibraltar, it was not present in any of the ten samples taken in the Alborán Sea between 373 and $1738 \mathrm{~m}$. Other faunistic studies performed in the Gulf of Cádiz at depths shallower than 700 m (Sardá et al., 1982; López de la Rosa, 1997), failed to detect the species. In the present samples, $H$. debilis only appeared in one of the 47 ottertrawl samples $(2 \%)$ taken south-west of the Balearic Islands 


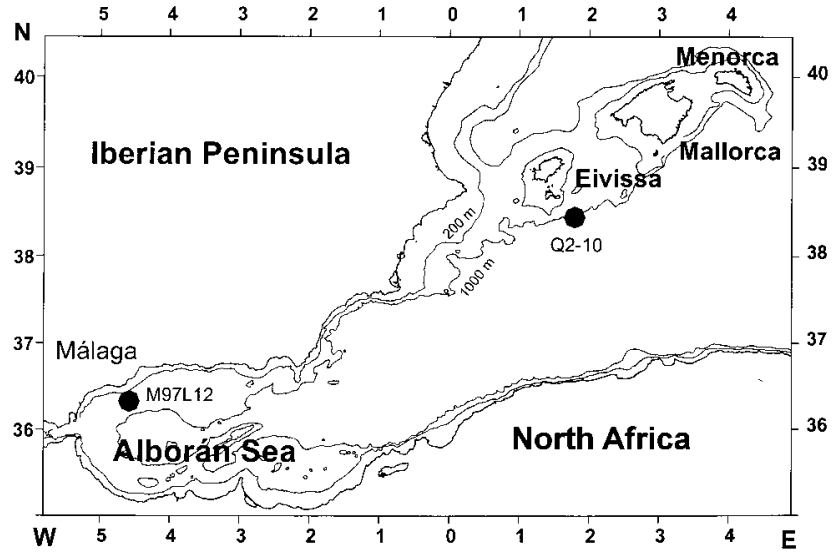

Figure 1. Map of the study area showing the two capture locations (M97L12 and Q210) of Hymenopenaeus debilis.

between 257-1714 m (QUIMERA-1 cruise) and in one of 191 otter-trawl samples $(0.5 \%)$ taken between 100 and $800 \mathrm{~m}$ south of latitude $39^{\circ} \mathrm{N}$ along the shores of the Iberian Peninsula and Balearic Islands (MEDITS-ES cruises). Therefore the population of $H$. debilis in the Mediterranean seems to be much scarcer than in the Atlantic part of the Strait of Gibraltar.

The capture of two individuals of $H$. debilis in two different and distant areas in the western Mediterranean may suggest that a well-established population inhabits the area. However, given the low occurrence of the species considering the relatively high sampling effort in the western Mediterranean, the fact that both specimens are juvenile individuals, and the known hydrological patterns of the region, the occurrence of $H$. debilis in Mediterranean waters may probably be better explained as a pseudopopulation of Atlantic origin (Bouchet \& Taviani, 1992). Thus, pseudopopulations would be supported by the influx of Atlantic epipelagic larvae entering the Mediterranean with the surface current through the Strait of Gibraltar, since the deep currents from the Mediterranean to the Atlantic would not favour the influx of both adult individuals and first stage larvae. Larvae from these species may be unable to metamorphose and to establish well-formed populations when settlement occurred below $200 \mathrm{~m}$, due to the particular characteristics of the deep Mediterranean with higher and constant temperature and salinity than corresponding Atlantic waters. This argument was already discussed for the occurrence of Penaeopsis serrata (Abelló \& Torres, 1998) in Mediterranean waters.

Within this context, Crosnier \& Forest (1973) cited a total of 30 species of tropical-subtropical benthic shrimps and prawns whose geographical distribution attain latitude $40^{\circ} \mathrm{N}$ (figure 119, p. 350). While 13 of these species had a bathymetric range distribution situated shallower than $200 \mathrm{~m}$ (Gibraltar sill reaches $280 \mathrm{~m}$ depth), 17 were distributed deeper than $200 \mathrm{~m}$ in the Atlantic Ocean. All species in the shallower group have wellrepresented populations both in the Mediterranean and Atlantic basins, while among deeper species, only Ligur ensiferus seems to have stable populations in the Mediterranean Basin (Cartes et al., 1994). In addition, an uncommon or accidental transport of planktotrophic larvae pertaining to the deeper group of Atlantic species could also explain - at least partially - the accidental capture of deeper Atlantic species (i.e. H. debilis) after the recently high sampling effort performed in the Alboran Sea and south-west Balearic Islands. Although the first argument may be supported by the critical biological process of ecdysis during crustacean growth, a low colonization hypothesis by planktotrophic larvae of deep sea species can also consistently be argued considering the possible effect of the westwards current of Mediterranean water exiting the Mediterranean Basin. The strong deep Mediterranean outflow occurring deeper than around 100-200 m near the Strait of Gibraltar probably impairs the colonization of surficial water layers by planktotrophic larvae of Atlantic deep sea species, a first step in their colonization of the Mediterranean Sea.

We wish to thank all participants in the cruises 'MEDITS-ES97' on board RV 'Cornide de Saavedra' and 'QUIMERA-2' on board RV 'García del Cid'.

\section{REFERENCES}

Abelló, P. \& Torres, P., 1998. Occurrence of Peneopsis serrata (Bate, 1881) (Decapoda, Penaeidae) in the Mediterranean Sea. Graellsia, 54, 115-117.

Bouchet, P. \& Taviani, M., 1992. The Mediterranean deep-sea fauna: pseudopopulations of Atlantic species? Deep-Sea Research, 39, 169-184.

Bouvier, E.L., 1908. Crustacés Décapodes (Pénéidés) provenant des campagnes de l'Hirondelle et de la Princesse Alice; 1886-1907. Résultats des Campagnes Sciéntifiques accomplies sur son Yacht par Albert I Monaco, 33, 11-22.

Burkenroad, M.D., 1936. The Aristeinae, Solerocerinae and pelagic Penaeinae of the Bingham oceanographic collection. Bingham Oceanographic Foundation, 5, 1-151.

Cartes, J.E., Company, J.B. \& Maynou, F., 1994. Deep-water decapod crustacean communities in the northwestern Mediterranean: influence of submarine canyons and season. Marine Biology, 120, 221-229.

Crosnier, A. \& Forest, J., 1973. Les crevettes profondes de l'Atlantique oriental tropical. Faune Tropicale ORSTOM, Paris, 19, 1-409.

García-Ladona, E., Castellón, A., Font, J. \& Tintoré, J., 1996. The Balearic current and volume transports in the Balearic basin. Oceanologica Acta, 19, 489-497.

García-Raso, J.E., 1996. Crustacea Decapoda (excl. Sergestidae) from Ibero-Moroccan waters. Results of Balgim-84 expedition. Bulletin of Marine Science, 58, 730-752.

González-Pérez, J.A., 1995. Catálogo de los Crustáceos Decápodos de las Islas Canarias. Cruz de Tenerife: Publicaciones Turquesa.

López de la Rosa, I., 1997. Crustáceos decápodos capturados durante las campañas del IEO ARSA 0393 y ARSA 1093 en el golfo de Cádiz: distribución batimétrica. Publicaciones Especiales del Instituto Español de Oceanografía, 23, 199-206.

Maurin, C., 1962. Étude des fonds chalutables de la Méditerranée occidentale (écologie et pêche). Résultats des campagnes des navires océanographiques 'Président Théodore Tissier' 1957 à 1960 et 'Thalassa' 1960 et 1961. Revue des Travaux de l'Institut de Pếches Maritimes, 26, 163-218.

Millot, C., 1987. Circulation in the western Mediterranean. Oceanologica Acta, 10, 143-149.

Noël, P.Y., 1992. Clé préliminaire d'identification des Crustacea Decapoda de France et des principales autres espèces d'Europe. Paris: Muséum National d'Histoire Naturelle.

Sardá, F., Valladares, F.J. \& Abelló, P., 1982. Crustáceos decápodos y estomatópodos capturados durante la campaña 'Golfo de Cádiz 81'. Resultados Expediciones Científicas, 10, 89-100. [Investigación Pasquera, Supplement.]

Send, U., Font, J., Krahmann, G., Millot, C., Rhein, M. \& Tintoré, J., 1999. Recent advances in observing the physical oceanography of the western Mediterranean Sea. Progress in Oceanography, in press.

Zariquiey-Alvarez, R., 1968. Crustáceos decápodos ibéricos. Investigación Pesquera, 32, 1-510. 